University of Warwick institutional repository: http://go.warwick.ac.uk/wrap This paper is made available online in accordance with publisher policies. Please scroll down to view the document itself. Please refer to the repository record for this item and our policy information available from the repository home page for further information.

To see the final version of this paper please visit the publisher's website. Access to the published version may require a subscription.

Author(s): Matthew Clayton

Article Title: 'Liberal Equality and Ethics'

Year of publication: 2002

Link to published version: http://dx.doi.org/10.1086/341324

Publisher statement: None 


\section{Liberal Equality and Ethics*}

\section{Matthew Clayton}

\section{LIBERAL EQUALITY}

Dworkin's conception of distributive justice, equality of resources, requires equality in the distribution of impersonal resources and compensation for personal resource deficits, or their consequences, to be determined by a fair hypothetical insurance scheme. Among other things, that conception offers a recognizably liberal account of interpersonal comparison for the purposes of justice. Consider the envy test, for example. Dworkin cites the envy test as a test for equality in the distribution of impersonal resources, such as wealth, land, occupation, and material goods. The test is satisfied if no one prefers anyone else's bundle of impersonal resources to her own. ${ }^{1}$ The attractions of the envy test within a liberal conception of equality are evident. First, it conforms to a widely held egalitarian view that an individual is disadvantaged if she enjoys less wealth than others because of the circumstances in which she lives (e.g., living in an area with less fertile land than others enjoy), rather than because of her ambitions. If Alice and Biff both hold the same goals but Alice faces a more propitious material environment in which to pursue hers, then both would prefer to be in her position. The envy test highlights those kinds of inequality as unjust. ${ }^{2}$

\footnotetext{
* This article derives from a presentation to a conference on Ronald Dworkin's Sovereign Virtue hosted by the University of London School of Advanced Study, Philosophy Programme, on March 23, 2001. I thank the participants at the conference for their comments. For other helpful comments I am grateful to Justine Burley, Paula Casal, Simon Clarke, Deborah Mabbett, Mark Philp, Katherine Watson, Martin Wilkinson, Andrew Williams, and an anonymous referee for Ethics.

1. Dworkin emphasizes that the envy test is a necessary, but not a sufficient, condition of equality in the distribution of impersonal resources. See Ronald Dworkin, Sovereign Virtue: The Theory and Practice of Equality (Cambridge, Mass.: Harvard University Press, 2000), pp. 67-68, 134-62.

2. Note that this view is widely, though not universally, shared by those who describe themselves as egalitarians. For a prominent alternative conception, see Elizabeth Anderson, "What Is the Point of Equality?" Ethics 109 (1999): 287-337; Timothy Hinton, "Must Egalitarians Choose between Fairness and Respect?” Philosophy E Public Affairs 30 (2001): 72-87.

Ethics 113 (October 2002): 8-22

(C) 2002 by The University of Chicago. All rights reserved. 0014-1704/2003/11301$0001 \$ 10.00$
} 
Second, the envy test's reliance on preferences in establishing whether inequality exists satisfies the liberal concern that justice must be sensitive to the diverse lifestyles pursued by different individuals. Some individuals may want to pursue a life of service to others and abandon a concern for personal monetary advantage, while others might choose to pursue wealth. Such heterogeneity of ambition is accommodated by the envy test. A distribution in which an individual who pursues a service-oriented occupation, which in the competitive market yields low income, is not, according to the envy test, disadvantaged compared to someone who pursues an alternative occupation for high income, if the former does not prefer the latter's bundle of wealth and occupation. ${ }^{3}$

Dworkin is, of course, aware that other conceptions of equality aspire to ambition sensitivity. He famously criticizes equality of welfare for being sensitive in the wrong way. A number of problems beset that conception, not least the problem of expensive tastes. ${ }^{4}$ Dworkin cites the case of Louis who has developed particular tastes, which make it the case that more impersonal resources are required to ensure that he acquires an equal level of welfare-understood in terms of either enjoyment or preference satisfaction. Equality of welfare is committed to financing Louis's tastes at the expense of reducing everyone else's level of welfare. Intuitively, while an egalitarian would not condemn Louis for having cultivated his tastes, neither would she require others to finance their satisfaction: Louis must accept that the price of having such tastes is a lower level of welfare. This kind of response is supported by the envy test. Since Louis does not prefer to be in anyone else's position compared to his own, he suffers no disadvantage that generates grounds for compensation from the perspective of justice. ${ }^{5}$

In summary, the envy test is able to explain the conviction that disadvantageous circumstances warrant egalitarian compensation, while differences in what individuals have that are attributable to their ambitions do not. ${ }^{6}$

3. Dworkin, Sovereign Virtue, pp. 83-85.

4. Ibid., pp. 48-59.

5. Note that Louis might be thought to be disadvantaged in a way that does not warrant compensation from the perspective of egalitarian justice. It might be bad luck for him that he lives in an environment in which the phyloxera has attacked great wineproducing vines, which makes it more costly to satisfy his preferences. Nevertheless, this disadvantage is consistent with the absence of any comparative disadvantage, as defined by the envy test, which would generate grounds for compensation from the point of view of egalitarian justice. For further discussion of the distinction between comparative and noncomparative disadvantage, and its relevance to Dworkin's reply to Cohen's critique of equality of resources, see Matthew Clayton, "The Resources of Liberal Equality," Imprints 5 (2000): 63-84.

6. Dworkin, Sovereign Virtue, p. 89. 
Certain standards of interpersonal comparison that have been defended in the debate about egalitarian justice-such as primary goods, capabilities, and access to welfare-list a set of goods, the possession of which is taken to be in the interests of individuals. ${ }^{7}$ In order to make good their claims that they are disadvantaged from the point of view of justice, individuals must establish that they lack the goods itemized as being in their interests while others enjoy them. In contrast, the envy test enables individuals to bring their own views about what is beneficial for them to bear on the question of whether they suffer a disadvantage. As Dworkin states, equality of resources "allows us to cite, as disadvantages and handicaps, only what we treat in the same way in our own ethical life." ${ }^{\prime}$ This requirement is attractive to many liberals because it provides an account of equality that refrains from appealing to a concrete conception of what makes one's life a success. What a "concrete" conception of well-being amounts to needs spelling out, but, for illustration, it might cite certain kinds of artistic or religious achievement, or the satisfaction of preferences, as components of a successful life. By avoiding an appeal to such a concrete conception of well-being as the basis of its account of advantage, Dworkin's resource egalitarianism respects a widely affirmed liberal constraint, that government must not prescribe any concrete conception of the good life for individuals or rely on such an account in the defense of its principles and policies. The envy test satisfies this requirement in its insistence that what counts as an advantage or disadvantage is to be determined with reference to the ambitions of the individuals whose advantage is under consideration.

This feature of equality of resources also provides an explanation of its objection to welfarist metrics of interpersonal comparison. For it does not allow a person to cite the lack of a particular good, such as preference satisfaction, as a disadvantage if she rejects welfare as a good when considering her own well-being. Thus, Louis cannot cite his expensive tastes as handicaps warranting egalitarian compensation, because his life is in part guided by the satisfaction of those tastes without which, he believes, his life would go worse. He cannot, in good faith, claim that he is less advantaged than others in virtue of his lower level of welfare, when he cares so little about welfare in his own life that he wouldn't be prepared to develop cheaper preferences that are more easily satisfied. ${ }^{9}$

7. For a critical survey of these conceptions, see Matthew Clayton and Andrew Williams, "Egalitarian Justice and Interpersonal Comparison," European Journal of Political Research 35 (1999): 445-64.

8. Dworkin, Sovereign Virtue, p. 294.

9. Dworkin argues that since Louis regards his tastes as an important part of his lifestyle, he is consequentially responsible for his tastes, in the sense that he must bear the burden of a lower level of welfare than others, even if he is not causally responsible 


\section{EQUALITY OF RESOURCES AND POLITICAL LIBERALISM}

Dworkin's own defense of the liberal aspect of equality of resources appeals to a controversial account of ethics and its relationship to justice. The evaluation of that defense is the principal concern of this article. Nevertheless, it is worth emphasizing that his account of resource egalitarianism and, in particular, its insistence on the relevance of firstperson judgments to the assessment of advantage might appeal to egalitarians who are attracted to political liberalism. Thus, liberal equality represents an alternative to justice as fairness as a political conception of justice.

Political liberals assert that, ideally, political principles and their justification should be capable of endorsement by free and equal individuals who hold different and possibly inconsistent comprehensive convictions. ${ }^{10}$ Now liberal equality requires individuals to assess whether they are disadvantaged compared to others in the light of their own distinctive comprehensive convictions. It therefore seems capable of gaining wider public acceptance as a test for equality compared to metrics that require individuals to express their claims for social funds on the basis of lacking particular goods, for example, welfare, even when the individuals concerned do not value such goods.

When Dworkin discusses political liberalism in the context of his defense of resource egalitarianism, he raises it as a possible basis on which to disregard individuals' own ambitions or judgments about what is required to live well. Thus, he employs it as providing grounds for objecting to equality of resources. The aim of such a political conception of justice is to obtain public acceptance of its principles by refusing an appeal to controversial ethical convictions in defending them and their methods of implementation. In an environment in which there exist divergent conceptions of the good life, Dworkin supposes that his critic would advocate "a special, made-for-politics morality,"11 a morality which all can accept and refer to in adjudicating their competing claims when acting as political agents, even if various individuals or groups reject that morality as an appropriate guide to their own ethical lives. Thus, Dworkin supposes that an advocate of equality of welfare might help himself to this strategy in order to rebut the reliance on individuals' ambitions that we find in resource egalitarianism. Were that strategy available, it would be open for a welfare egalitarian to argue that even though an individual doesn't value welfare in his own life, that need

for them. See ibid., pp. 285-99. For further discussion of Dworkin's critique of equality of welfare and his response to metrics that include equality of access to welfare, see Clayton, pp. 72-84.

10. See John Rawls, Political Liberalism (New York: Columbia University Press, 1993). 11. Dworkin, Sovereign Virtue, p. 294. 


\section{Ethics October 2002}

not make it inappropriate for us (and him) as political agents to adopt welfare as the metric for making interpersonal comparisons with regard to matters of justice. Dworkin's response is that his liberalism is drawn from an account of personal ethics and is, therefore, antagonistic to the notion of a "made-for-politics" account of advantage. ${ }^{12}$

However, it is important to distinguish between two ways in which the political liberal's concern for public acceptance of a conception of justice might be delivered. The first is Dworkin's thought that she would describe a "made-for-politics morality," which insists on the importance of citizens obtaining certain goods, even when the possession of such goods is regarded by some individuals as an impediment to the pursuit of their own ethical commitments. The second strategy is to fashion a standard of interpersonal comparison that accommodates, rather than disregards, the ethical convictions of different individuals by permitting each to express her claims for compensation by citing a lack of items that she regards as helpful in the realization of her own ambitions. The accommodation strategy objects to metrics that list a number of goods on the basis of which different lives can be compared, because any list will include goods whose value is questioned by some. Liberal equality fits the bill of the accommodation strategy well, since it does not prescribe any list of that kind. Indeed, by allowing individuals to bring their own convictions to the egalitarian table, it is better suited to the ideals that animate political liberalism than the made-for-politics metric. Thus, since political liberals might follow a strategy of accommodation to achieve public agreement on their principles of justice, they are free to adopt liberal equality as their conception of justice. ${ }^{13}$

\section{ETHICAL GROUNDS FOR LIBERAL EQUALITY}

Dworkin's own argument for liberal equality appeals to a controversial account of ethics. He describes an account of ethics, the challenge model, in which living well consists in responding in the right way to an appropriate challenge. His argument is that liberal equality is the conception of justice best suited to the requirements of the challenge model.

Before we proceed to examine the challenge model's defense of

12. Ibid., pp. 294-96.

13. Note, however, that certain political liberals might think that the accommodation of different comprehensive doctrines that liberal equality effects comes at a price. As Rawls insists, one attractive feature of primary goods as a standard of interpersonal comparison is their workability within a public conception of justice. See John Rawls, The Law of Peoples (Cambridge, Mass.: Harvard University Press, 1999), p. 13. In contrast, the use of the envy test and hypothetical insurance schemes within liberal equality rely upon complex counterfactual judgments that are difficult to make and which might jeopardize citizens' confidence that justice prevails. 
liberal equality, we must note that Dworkin insists that liberal equality does not rely on this particular ethical defense. ${ }^{14} \mathrm{He}$ advertises an alternative ethical account, ethical individualism, which, he believes, has fewer detractors and is sufficient to support liberal equality. That account offers two principles-the equal objective importance of human lives and individuals' special responsibility for the lives they choose-as the bases of the distinction, at the center of liberal equality, between ambition sensitivity and endowment insensitivity in the distribution of resources. Ethical individualism is elaborated in Dworkin's 1998 Dewey Lectures, "Justice for Hedgehogs." Its evaluation must await another occasion.

Here, I want to consider Dworkin's appeal to the challenge model in defense of liberal equality. The model is interesting and has received critical scrutiny in its own right as a conception of how to live well. ${ }^{15}$ However, my present interest in it is limited. The question that I address is whether the challenge model, if sound, provides sufficient grounds for liberal equality. In particular, can liberal equality's reliance on individuals' own judgments about whether they are disadvantaged compared to others be supported by appeal to the challenge model?

The task for any ethical defense of liberal equality is simple to state. If we start with what we take to be the best account of what it means to live a successful life, we must show how that account gives us reason to allow individuals to employ their own, possibly inadequate, conceptions of the good life in the assessment of whether they are disadvantaged. For it is not obvious that the accommodation of different ethical convictions, which equality of resources effects, is warranted by the right conception of ethics. Consider, for example, certain perfectionists who hold that lives devoted to religious worship are less successful than many alternative lifestyles, because they are premised on false beliefs or involve the pursuit of projects that lack value. If these judgments are sound, and if we think it appropriate, as Dworkin does, for politics to flow from ethics, then it might be thought just to offer in-kind compensation to individuals who, because of their family or social background, have been deprived of an equal opportunity to experience or engage in valuable lifestyles. Political institutions might, in addition, encourage the pursuit of more fulfilling lifestyles through the granting of public subsidies to these alternatives.

The problem is that these proposals, for in-kind compensation or subsidies for worthy causes, violate a couple of features of equality of

14. Dworkin, Sovereign Virtue, p. 241.

15. See, e.g., Martin Wilkinson, "Dworkin on Paternalism and Well-Being," Oxford Journal of Legal Studies 16 (1996): 433-44; Richard Arneson, "Human Flourishing versus Desire Satisfaction,” Social Philosophy and Policy 16 (1999): 113-42, esp. pp. 135-42. 


\section{$14 \quad$ Ethics $\quad$ October 2002}

resources. First, if we adopt these proposals, the standard of interpersonal comparison that we favor is likely to be one that determines the terms in which others phrase their requests for compensation. Instead of being allowed to bring one's own religious convictions to the egalitarian table, as liberal equality would have it, we would be required to make our claims for compensation by reference to the right, in this case humanist, account of ethics. Second, liberal equality requires equality in the opportunity costs that others must bear with respect to each individual's bundle of resources. But if the government subsidized a particular activity, such as the activities of humanist or valuable nonreligious societies, the distribution of resources would thereby become unequal, because the opportunity costs to others of a humanist life would be higher than those of a religious life: the humanist would enjoy more resources being devoted to his goals, resources which might have been given to the devout to pursue theirs. ${ }^{16}$

Dworkin's response to this kind of argument is that it rests on a mistaken account of ethics. He draws a distinction between two levels of ethical inquiry. First, there are "the more abstract levels at which we puzzle, not about how to live in detail, but about the character, force, and standing of the very question of how to live" and consider, for example, why living well has importance, who is responsible for ensuring that individuals' lives are successful, and the metric with which to judge whether someone's life goes well. Second, there are the concrete levels of ethics at which we worry about, for example, whether "a good life is necessarily a religious one." ${ }^{17}$ On the basis of this distinction, Dworkin argues that the right abstract account of ethics requires us to adopt a conception of distributive justice that does not take a stand on the merits of different people's concrete ethical convictions. In what follows I examine what I take to be the two central arguments Dworkin offers in defense of equality of resources' reliance on individuals', possibly inadequate, concrete ethical convictions.

\section{THE CHALLENGE MODEL AND THE GOODS OF IDENTIFICATION}

The first set of claims that I want to look at concerns the importance of individual identification with respect to the lives people pursue. According to the challenge model, living well consists in responding in

16. I am assuming, however, that while the distribution of resources would be unequal according to liberal equality, these proposals are supported by a conception of equality that is motivated by some ideal of equal access to valuable activities. To be sure, it is no part of these proposals that those who hold sound views of well-being deserve more resources than those who hold mistaken views. The proposed subsidies are motivated by the concern to equalize access to human flourishing.

17. Dworkin, Sovereign Virtue, pp. 239-40. 
the right way to the right challenge. What matters then is a particular kind of performance and not merely the outcome, considered independently of the performance, that is produced by one's life. And Dworkin insists that the motives from which one acts are relevant to the evaluation of that performance.

Let us distinguish between two ways in which identification might matter when assessing whether an individual lives well. First, Dworkin insists that a person's pursuit of particular goals, projects, or relationships can contribute to the success of his life only if he identifies with them. This is summarized in Dworkin's account of ethical integrity: "Someone has achieved ethical integrity, we may say, when he lives out of the conviction that his life, in its central features, is an appropriate one, that no other life he might live would be a plainly better response to the parameters of his ethical situation rightly judged." ${ }^{18}$ A person who identifies with a different feasible lifestyle to the one he leads lacks ethical integrity, and, no matter how well he pursues the activities of his life, they fail to benefit him, because ethical integrity is a necessary condition of living well.

Second, Dworkin insists that living well requires not merely identifying with one's life. It also requires the individual himself to identify, or choose, the central goals, projects, and relationships which make up his life: "the most important part of the challenge people face in leading a life . . . is identifying life's value for themselves." ${ }^{19}$ The good of identifying the commitments and projects the pursuit of which would improve one's life goes beyond the claim that it is necessary for an individual to identify with his life, for plainly one can come freely to identify with one's life even if one didn't choose it from the outset. Dworkin's case of the child who is forced into taking piano lessons but who comes to accept that they did make his life go better is an example of how the two sorts of identification can be distinguished..$^{20}$

Note that Dworkin thinks that the quality of one's concrete goals, projects, and relationships does contribute to the success of one's life. Playing the piano well, for example, might improve one's life if one accepts its value, while being a couch potato might not. So Dworkin distances himself from those who believe that an individual's identification of, or with, his ethical life is sufficient for his life to go well. ${ }^{21}$

Since that is the case, a perfectionist critic might seek to show that a conception of distributive justice that encouraged the pursuit of particular concrete conceptions of the good would improve people's lives.

18. Ibid., p. 270.

19. Ibid., p. 277.

20. Ibid., p. 269.

21. Ibid., pp. 271-72. 
She would have to show how the particular distribution of resources she favors would get individuals to abandon goals that lack value and to adopt high quality goals, without jeopardizing the goods of identification.

In his discussion of the goods of identification, Dworkin explains how the priority of ethical integrity and the good of identifying life's value for oneself render various kinds of state paternalism self-defeating. $\mathrm{He}$ also employs these ideas to support liberal equality. He considers the proposal that a government might choose a particular conception of wellbeing and use it to judge the success of the lives of different individuals for the purposes of determining what justice requires. One of his replies is that "ethical liberals could not accept this, because government would then usurp the most important part of the challenge people face in leading a life, which is identifying life's value for themselves." 22

But consider the proposal outlined above, in which the humanist offers an account of distributive justice which subsidizes the pursuit of high quality activities and regards as disadvantaged individuals who, through no fault of theirs, lack the opportunity to pursue such high quality nonreligious pursuits. Under that conception of justice, any claim for compensation would have to show how possession of additional resources would enable the person in question to pursue such goals more successfully. A person who proposed to spend any additional resources he might receive entirely on religious pursuits could offer no such claim.

But in what sense does the humanist's proposal violate the goods of identification? First, she does not seek to use force to make believers lead lives the value of which they reject. And, second, her proposal seems consistent with the requirement that individuals should choose the goals and relationships that make up their lives. For the proposal does not eliminate any lifestyle from the menu of options available to individuals; it merely changes some of the costs and benefits derived from them. ${ }^{23}$ If these claims are sound, then the goods of identification are compatible with the rejection of equality of resources. Thus, the complaint of someone who has fewer resources devoted to his religious life, compared to the amount that subsidized nonbelievers receive, is

22. Ibid., p. 270.

23. One other component of ethical integrity which bears on this issue concerns the conditions under which a change of identification with respect to a particular lifestyle can be said to be genuine. Such a change is compatible with ethical integrity only if it is effected through an individual's reflective appreciation of the comparative merits of different lifestyles. This important condition requires the elaboration of a conception of liberal education and motivates a concern that subsidies are not so great that the deliberative capacities of individuals are inhibited. For discussion, see ibid., pp. 218, 272-74. But while this concern might affect the size of the subsidies offered to valuable activities, it does not, I believe, rule them out as a matter of principle. 
not forceful in virtue of him being deprived of the goods of identification. In addition, since the subsidization of valuable pursuits is designed to contribute to people's well-being by facilitating a change of identification, there seem to be positive reasons to depart from equality of resources. ${ }^{24}$

One response to this argument for departing from liberal equality might point out that if the government changed the costs and benefits of different concrete lifestyles by subsidizing certain activities, it would be usurping the challenge individuals face in terms of identifying life's value for themselves. For the environment in which they live is one that is determined by the fact that others see the value of these lifestyles, while they themselves do so to a lesser extent. Consequently, they cannot take full credit for identifying the life they lead if they do indeed follow the high-quality subsidized options.

However, even if a response of this kind were available, it is unlikely that it would support liberal equality. Under liberal equality, if I understand it correctly, private individuals are free to subsidize what they take to be valuable activities or relationships if it is part of their ambition to encourage others to lead better lives. But if the good of choosing a life for oneself rules out government subsidies for valuable activities, it seems that it must also rule out individuals choosing to use their resources to subsidize such activities. ${ }^{25}$

Consider a possible reply to this objection. It might be thought too difficult for public agencies to distinguish between inappropriate philanthropic activity by individuals and their self-regarding conduct that, while permissible, has similar effects with respect to the choices other people face. Consequently, a legal prohibition on private subsidies could be enforced only at the cost of jeopardizing the ethical goods that liberal egalitarians aspire to protect, namely, the goods of individuals identifying and pursuing lifestyles in their own way. In this respect, there is a relevant distinction between public and private ethics, for, unlike private individuals, the state has no life of its own to lead which would be threatened by a ban on its subsidizing valuable activities.

Even if this reply retains a place for private philanthropy within liberal equality, however, it is not obvious that it preserves the right kind of place. For the conception of civil life at the center of many concep-

24. For related discussion, see Thomas Hurka, "Indirect Perfectionism: Kymlicka on Liberal Neutrality," Journal of Political Philosophy 3 (1995): 36-57, esp. pp. 49-50; Colin Macleod, Liberalism, Justice and Markets: A Critique of Liberal Equality (Oxford: Clarendon, 1998), chap. 7.

25. Here I follow Raz's objection to a similar argument offered by Waldron. See Joseph Raz, "Facing Up: A Reply," Southern California Law Review 62 (1989): 1153-1235, pp. 1233-35; Jeremy Waldron, "Autonomy and Perfectionism in Raz's Morality of Freedom," Southern California Law Review 62 (1989): 1097-1152, see esp. pp. 1147-49. 
tions of liberalism, Dworkin's included, is one in which individuals regard themselves as morally, as well as legally, permitted to engage in evangelical and philanthropic activity, including the use of monetary resources to present their lifestyles in their best lights and to encourage others to pursue them. Yet, if we consider the moral permissibility of subsidies from the point of view of liberal equality, public and private variants stand or fall together.

\section{LIBERAL EQUALITY AS A PARAMETER}

We have seen that the challenge model interprets living well as responding in the right way to the right challenge. A second argument for liberal equality focuses on how we ought to characterize the notion of an appropriate or right challenge. Before I get to that argument, let me fill in some detail about the notion of facing the right challenge.

An attractive feature of the challenge model is that it can explain how it is possible for different kinds of life to be valuable, depending on the circumstances within which they are pursued. As Dworkin says, "a life of chivalrous and courtly virtue might have been a very good one in twelfth century Bohemia but not in Brooklyn now." ${ }^{26}$ That is the case because different circumstances produce different challenges, each requiring distinct responses and associated virtues for the challenge to be appropriately met. Dworkin puts the point in terms of the distinction between limitations and parameters. In living our lives, the circumstances in which we operate often constitute limitations on, or aids to, what we have reason to pursue. Nevertheless, certain aspects of our condition are parameters, which are partly constitutive of the challenge we face. If we view well-being in terms of a successful response to the challenge we face, we should regard certain facts, such as our being human and certain capacities and attachments that we have, as contributing to the definition of that challenge. ${ }^{27}$

Dworkin proceeds to discuss normative parameters, which are those circumstances that should constitute the background from which one responds to the challenge of living. He offers a reasonable lifespan as an example of a normative parameter: a significantly shorter lifespan deprives one of an appropriate challenge. This enables him to complete the abstract characterization of the challenge model of ethics: "Living well means responding in the right way to the right challenge . . a a life goes worse when the right challenge cannot be faced." ${ }^{28}$ Of particular relevance for an assessment of Dworkin's liberalism is his view that justice

26. Dworkin, Sovereign Virtue, p. 258.

27. Ibid., pp. 260-63.

28. Dworkin, "Foundations of Liberal Equality," in The Tanner Lectures on Human Values, vol. 11, ed. Grethe B. Peterson (Salt Lake City: University of Utah Press, 1990), p. 73. 
is a parameter, in the sense that if someone holds an unjust share of resources, he faces the wrong challenge, and it is unlikely that any achievement of his life can compensate for that defect.

How does the notion that living well requires a just share of resources support Dworkin's claim that liberal equality is the best account of justice? So far as I understand it, his argument is that treating justice as a parameter of ethics means that we cannot offer an account of living well without reference to the notion of justice. So, for example, we cannot offer an itemization of goods, such as being educated, healthy, financially secure, and so on, the possession of which would fundamentally improve someone's life, irrespective of whether the distribution of such goods is just or unjust. For the possession of such goods may not contribute to one's well-being if one enjoys an unjust share of them. Thus, conceptions of justice that proceed from a conception of wellbeing defined without reference to norms of justice, and then theorize justice as, say, equal access to well-being, mistakenly suppose that our interests can be defined independently of an assessment of what justice demands. Similarly, our humanist's proposal, that we can distribute resources in a manner that encourages individuals away from unworthy pursuits into worthy ones, errs in supposing that we can identify what would be good for people independently of identifying what a fair share of resources would be.

The conclusion Dworkin defends is that theorizing justice as a fair compromise between different individuals' competing interests is mistaken. Because living well depends upon living within just arrangements, those arrangements must be conceptualized without appealing to a conception of well-being that is defined without reference to justice. However, advocates of certain metrics of egalitarian justice-such as welfare, access to welfare, or capability accounts-do claim that these goods serve our well-being, and that this can be established before we address the question of whether their distribution is just or unjust. According to Dworkin, those accounts are untenable if justice is a parameter of the good life. ${ }^{29}$

Because justice is a parameter of ethics, Dworkin claims that in defending a conception of justice we must appeal to intuitions about justice in the absence of a detailed account of well-being. We do, of course, have an abstract understanding of well-being, provided by the challenge model, which, Dworkin claims, favors an egalitarian conception of justice: the challenge model interprets living well as an appropriate response to the challenge of living and is therefore addressed to 92-98.

29. See Dworkin, Sovereign Virtue, pp. 277-78, "Foundations of Liberal Equality," pp. 
anyone who lives. ${ }^{30}$ Nevertheless, that abstract account cannot indicate in any detail what is good for people, because whether the possession of a particular item is good for someone depends upon whether its possession is consistent with justice.

Let us accept Dworkin's claim that an adequate conception of justice is egalitarian. ${ }^{31}$ Are there good grounds for adopting resource egalitarianism over, say, equal access to welfare? If successful, the justice-asparameter-of-ethics argument rules out arguments for access to welfare as the best metric of egalitarian justice if the defense of its adoption is that it is required by the right conception of well-being. However, as Dworkin himself points out, welfare might be taken to be an appropriate standard of interpersonal comparison when issues of distributive justice arise, even if it is rejected as a characterization of well-being. ${ }^{32}$ Nevertheless, as we have noted, Dworkin argues that welfarist conceptions are inadequate as metrics of justice, even when we consider them purely as metrics for dealing with issues of justice without invoking them as accounts of well-being as well. ${ }^{33}$

Dworkin's claim is that if justice must be theorized independently of a detailed account of well-being, then some version of equality of resources is the best conception available. That claim has considerable plausibility. I am less convinced by the antecedent claim, that we cannot invoke some reasonably detailed conception of well-being when thinking about justice, even if we accept the parametric status of justice with respect to the good life.

Suppose that justice is a hard parameter of ethics ${ }^{34}$ and, in addition,

30. Dworkin, Sovereign Virtue, p. 279.

31. That concession is controversial. Even if resources are the appropriate means of conferring a challenge, it does not follow from the fact that the challenge of living is addressed to anyone who lives that resources should be distributed equally. Some might argue that successfully overcoming the limitations imposed on one by a physical or mental impairment makes one's life just as much a success, or perhaps more of a success, compared to performing well in life without such impairments. The success of an individual's life might be determined by her response to the challenge that nature, among other things, sets her, even if the distribution of natural resources is unequal between individuals. So, the inference from the universality of the challenge of living to an egalitarian conception of its content requires more justification than Dworkin offers. Since my primary focus is on the liberal component of equality of resources, however, I put this issue to one side.

32. Dworkin, Sovereign Virtue, pp. 19-21. For a similar suggestion, see T. M. Scanlon, "The Moral Basis of Interpersonal Comparisons," in Interpersonal Comparisons of Well-Being, ed. Jon Elster and John Roemer (Cambridge: Cambridge University Press, 1991).

33. Dworkin, Sovereign Virtue, chaps. 1, 7. See, in particular, his discussion of the problem of expensive tastes.

34. Note that Dworkin thinks that justice is merely a soft, rather than a hard, parameter of living well. That is, the life of someone who enjoys an unjustly large share of resources is "not automatically worthless, and might be a very good life" (ibid., p. 266). He illustrates this with the examples of Michelangelo, whose great works were financed by the Medici, 
that justice is viewed in access egalitarian terms. Why cannot considerations of well-being considered independently of justice figure in the determination of such a conception of justice? Given our assumptions, we might ask the following hypothetical question: "what would benefit individuals if different individuals enjoyed equal access to such goods?" Because that question is coherent and invites a number of possible replies, there is a space for a perfectionist egalitarian account of interpersonal comparison. For example, offering access to education, art or culture, or opportunities for the development and exercise of various virtues might enhance people's well-being if the government ensured that all enjoyed equal access to such goods. Since this is the case, a perfectionist egalitarian may offer an account of justice understood in terms of equal access to goods related to human flourishing. Treating justice as a parameter of ethics provides no reason why the metric of egalitarian justice must be theorized in ethically neutral, resourcist terms.

To be sure, the challenge model remains antagonistic to certain metrics of egalitarian justice, such as equal access to welfare, but that is for reasons other than their failure to accommodate the parametric status of justice. Welfarism remains an inadequate conception of living well because it is blind to the insight that well-being is fundamentally about meeting an appropriate challenge. Nevertheless, other perfectionists might embrace that insight and offer an account of justice that seeks to equalize citizens' access to valuable challenges. In doing so, they might resist equality of resources as the best interpretation of that ideal, for, as we have established, the resourcist conception seeks to accommodate individuals' misconceptions about what constitute valuable challenges as well as their rightly judged conceptions. In resisting liberal equality, such perfectionists might develop some of Dworkin's own remarks about worthwhile challenges. For example, he claims that, other things equal, a challenge is more valuable if it offers individuals the opportunity for "a more exciting, diverse, complex, and creative life." ${ }^{35}$ Granting that justice is a parameter, a perfectionist might advocate an equalization of opportunities to pursue such valuable challenges, which may well support the subsidization of particular lifestyles that our humanist proposes. Thus, Dworkin's intriguing claim that jus-

and the case of a child who would have died but for her parents' use of their unjustly high income to purchase expensive life-saving medical care for her. So, Dworkin does not believe that living under just social institutions is a necessary condition of living well, but this does not, I believe, affect the force of his argument which appeals to justice as a parameter of ethics in criticism of conceptions of justice that rest on some reasonably detailed account of well-being.

35. Ibid., p. 265. Dworkin illustrates the point with the claim that chess offers a more valuable challenge than tictactoe. 


\section{$22 \quad$ Ethics October 2002}

tice is a parameter with respect to ethics turns out to be compatible with a substantive conception of what a valuable challenge consists of, which can be employed as an alternative to the resourcism of liberal equality.

This does not, of course, end the debate. The argument I have offered is that a concern to advance individuals' well-being, as understood by the challenge model, does not prevent us from employing some reasonably concrete conception of what a successful life consists of to ground claims of distributive justice. Nevertheless, even if he accepted the arguments offered above, Dworkin might reply that we ought to resist such a move for some other reason. Perhaps employing such concrete information about well-being cannot be squared with other intuitions that we have about distributive justice. Or perhaps Rawls is right in claiming that the requirement that standards of interpersonal comparison be publicly justifiable implies that we have reason not to appeal to comprehensive doctrines when fashioning a metric of justice. ${ }^{36}$ All I have taken issue with is one of Dworkin's arguments, which claims that the challenge model of ethics supports liberal equality. As I have indicated, there are other ethical arguments for liberal equality-the "justice for hedgehogs" argument, for example-as well as arguments that defend it by appeal to goods other than that of living well. 